\title{
Isolation and Partial Characterization of Homogeneous Ferredoxin-sulfite Reductase from a Red Alga, Porphyra yezoensis
}

\author{
Osamu Koguchi and Goro TAMURA* \\ Department of Agricultural Chemistry, Faculty of Horticulture. \\ Chiba University, Matsudo, Chiba 271, Japan \\ Received January 20, 1989
}

\begin{abstract}
Ferredoxin-dependent sulfite reductase (Fd-SiR) (EC 1.8.7.1) was purified about 1136-fold, with a yield of $11 \%$, from fresh thalli of Porphyra yezoensis by a procedure involving ammonium sulfate precipitation, DEAE-cellulose chromatography, Butyl-Toyopearl chromatography, Sephadex G-100 gel filtration and ferredoxin-Sepharose affinity chromatography. The purified enzyme was apparently homogeneous, as judged on polyacrylamide disc gel electrophoresis, with a specific activity of 100 units/mg of protein. The molecular weight of the enzyme was estimated to be 70 kilodaltons by gel filtration. On subunit analysis by SDS-PAGE, a single band corresponding to molecular weight of 65 kilodaltons appeared. The purified enzyme (Fd-SiR) showed 5-times higher ferredoxin-dependent activity than methyl viologen-linked activity. In the oxidized form, the enzyme exhibited absorption maxima at 278, 390 (Soret band), 586 ( $\alpha$ band) and 714 (CT band) nm, indicating that siroheme is involved in the catalysis of sulfite reduction. The absorbance ratios, $A_{390}: A_{278}$ and $A_{586}: A_{390}$, were 0.32 and 0.31 , respectively. A plot of the substrate (sulfite) and electron donor (ferredoxin) concentrations versus enzymatic (Fd-SiR) activity yielded sigmoidal curves, giving Hill coefficients $(\bar{n})$ of 2.3 (for sulfite) and 2.7 (for ferredoxin), respectively. Antibody against the isolated enzyme was raised in rabbits. Analysis of the antiserum by immunodiffusion suggested that it was specific against isolated Fd-SiR. Using the antiserum, dot immunoblotting was performed to determine the immunological similarity of Fd-SiRs from Porphyra yezoensis, Spirulina platensis, Brassica chinensis and Spinacia oleracea. The tests revealed that the four forms of assimilatory Fd-SiR have antigenic determinants in common.
\end{abstract}

Sulfite reduction, observed in photosynthetic algal cells, is generally considered to be the final step of assimilatory sulfate reduction, in which sulfite is reduced to the level of sulfide according to the following equation. ${ }^{1 \sim 6)}$

$$
\mathrm{SO}_{3}^{2-}+6 \mathrm{e}^{-}+6 \mathrm{H}^{+} \longrightarrow \mathrm{S}^{2-}+3 \mathrm{H}_{2} \mathrm{O}
$$

This reaction step is catalyzed by the enzyme, sulfite reductase $(\mathrm{SiR}){ }^{1,2,5)}$ Some information on a red algal (Porphyra yezoensis) SiR has been obtained through experiments with an artificial dye, reduced methyl viologen (MV), as an electron donor. ${ }^{4,5}$ )

Recently, however, photoreduced ferre- doxin (Fd) was reported to be a physiological electron donor in a cyanobacterial (formerly blue-green algal) (Spirulina platensis) sulfite reductase system. ${ }^{7)}$ Although MV-SiR (hydrogen-sulfite: (acceptor) oxidoreductase, EC 1.8.99.1) of Porphyra yezoensis has been highly purified and extensively characterized, the purified enzyme has been demonstrated to be unable to couple with reduced ferredoxin. ${ }^{8)}$ In addition to this MV-SiR, we wish to report the purification of a ferredoxin-dependent SiR (Fd-SiR) (hydrogen sulfite: ferredoxin oxidoreductase, EC 1.8.7.1) from a red alga, Porphyra yezoensis.

Abbreviations: SiR, sulfite reductase; SDS-PAGE, sodium dodecyl sulfate polyacrylamide gel electrophoresis; Fd, ferredoxin; TGK-100 buffer, $50 \mathrm{~mm}$ Tris $-\mathrm{H}_{2} \mathrm{SO}_{4}$ buffer $\mathrm{pH} 7.8$, containing $10 \%$ glycerol and $100 \mathrm{mM} \mathrm{K}_{2} \mathrm{SO}_{4}$; CT band, charge transfer band.

* To whom reprint requests should be addressed. 


\section{Materials and Methods}

Materials. Fresh thalli of Porphyra yezoensis, grown in Tokyo Bay in the winter, were kindly supplied by $\mathrm{Mr}$. Araki of the Yamamoto Nori Research Laboratory Porphyra and spinach ferredoxins were purified by the method of Tagawa and Arnon ${ }^{9)}\left(A_{422}: A_{277}=0.45\right)$. Ferredoxin-Sepharose was prepared by the method of Shin and Oshino. ${ }^{10}$ 5-Deazariboflavin was prepared by the method of Yoneda. ${ }^{11}$

The following chemicals were purchased from commercial sources: DEAE-cellulose (DE-52) (Whatman Ltd); Sephadex G-100 (Pharmacia Fine Chemicals); Coomassie brilliant blue G 250 (Fluka AG); a calibration protein kit (ovalbumin, bovine serum albumin, aldolase, catalase and ferritin) (Boehringer Mannheim); and a SDS-PAGE calibration protein kit (phosphorylase $b$, albumin, ovalbumin, carbonic anhydrase, trypsin inhibitor and $\alpha$-lactalbumin) (Pharmasia Fine Chemicals). Toyopearl HW-55 and Butyl Toyopearl $650 \mathrm{~s}$ were kindly supplied by TOSOH Mfg. Co. Other chemicals were of analytical grade.

Assaying $F d$ - and $M V$-SiR activities. The assay method for Fd-SiR activity was the same as that described previously. ${ }^{7.12)}$ One unit of Fd-SiR activity was defined as the amount of enzyme which caused the oxidation of $1 \mu \mathrm{mol}$ of reduced ferredoxin per min under the assay conditions described. MV-SiR activity was measured spectrophotometrically at $25^{\circ} \mathrm{C}$ under anaerobic conditions in a Thumberg-type cuvette (light path, $1 \mathrm{~cm}$ ). The standard assay mixture contained $50 \mathrm{~mm}$ Tris $-\mathrm{H}_{2} \mathrm{SO}_{4}$ buffer, $\mathrm{pH}$ $7.8,2 \mathrm{~mm}$ EDTA, $0.03 \mathrm{~mm}$ 5-deazariboflavin, $0.2 \mathrm{~mm}$ methylviologen, $50 \mu \mathrm{l}$ of an appropriately diluted enzyme preparation and $1 \mathrm{~mm}$ sodium sulfite, in a total volume of $2 \mathrm{ml}$. The absorption at $604 \mathrm{~nm}$ of the solution in a cuvette was recorded and then the cuvette was illuminated with a PRR-500-W lamp placed $5 \mathrm{~cm}$ away from it. After incubation for $2 \mathrm{~min}$, the reaction was started by adding sodium sulfite from the side arm and the change in absorbance at $604 \mathrm{~nm}$ was followed. One unit of MV-SiR activity was defined as the amount of enzyme which caused the oxidation of $\mathrm{I} \mu \mathrm{mol}$ of reduced methyl viologen per min under the assay conditions described.

Physical and chemical measurements. Spectrophotometric determinations were performed with a Hitachi U-3200 and a Hitachi 556 double beam spectrophotometer using $1 \mathrm{~cm}$ light-path cuvettes. Molecular weight estimation by SDSPAGE was performed by the method of Laemmli. ${ }^{13}$ Analytical PAGE was performed by the method of Ornstein and Davis. ${ }^{14)}$ The amino acid composition was determined with a high sensitivity amino acid analyzer (Hitachi 835 Amino Acid Analyzer) after a sample had been hydrolyzed with $6 \mathrm{~N} \mathrm{HCl} \mathrm{for} 24 \mathrm{hr}, 48 \mathrm{hr}$, or $72 \mathrm{hr}$ at $100{ }^{\circ} \mathrm{C}$ in an evacuated sealed tube. The protein content was determined by the method of Bradford ${ }^{15\}}$ using bovine serum albumin as a standard.
Preparation of antiserum against Fd-SiR. Homogeneous Porphyra Fd-SiR (about $1 \mathrm{mg}$ ) emulsified with complete Freund's adjuvant (Difco Laboratories) was administered subcutaneously to a New Zealand white rabbit. Booster injections were given fourth at two week intervals, with the same amount of antigen. At two weeks after the final injection, whole blood was obtained. This allowed to stand at $37^{\circ} \mathrm{C}$ for $1 \mathrm{hr}$ and then at $4^{\circ} \mathrm{C}$ overnight, and then the serum was obtained by centrifugation. Serum from an unimmunized rabbit was used in the control experiment. The antiserum was used without further purification.

Dot immunoblotting analysis. The Fd-SiR solution was spotted onto dry Biodyne nylon membrane paper strips $(2.5 \times 5 \mathrm{~cm})$ with a Drummond microdispenser. The peroxidase activity on the sheet was detected by the method of Nakane. ${ }^{16)}$

\section{Results}

\section{Enzyme purification}

All the purification procedures were carried out in a cold room maintained at $0 \sim 4^{\circ} \mathrm{C}$. Unless otherwise stated, dialysis was performed overnight against the indicated buffer.

Step 1. Preparation of a crude extract. Porphyra thalli were washed several times with tap water to free them from salts and then, with the addition of several drops of toluene, subjected to autolysis in two volumes of $0.2 \mathrm{M}$

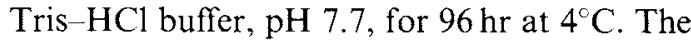
autolysate thus obtained was filtered through cheesecloth with the aid of a hand press and the filtrate was used as the crude extract. One kilogram (wet weight) of thalli was used in this experiment.

Step 2. Acrinolum fractionation. To the above crude extract, a $1 \%$ acrinolum solution was added slowly with stirring to $0.04 \%$. The mixture was stirred for an additional $10 \mathrm{~min}$ and the precipitate was removed by filtration through a layer of absorbent cotton. To the filtrate obtained above were added 2-mercaptoethanol, phenylmethylsulfonyl fluoride and polyclar AT to final concentrations of $10 \mathrm{~mm}$, $0.5 \mathrm{~mm}$ and $5 \%$, respectively. The resulting solution was filtered through cheesecloth.

Step 3. Ammonium sulfate fractionation. Solid ammonium sulfate was slowly added to the filtrate from the preceding step $(750 \mathrm{ml})$ to obtain $30 \%$ saturation. After removing 
the resulting precipitate by centrifugation $(10,000 \times g$ for $20 \mathrm{~min})$, ammonium sulfate was further added to the supernatant to final $85 \%$ saturation. The precipitate formed was collected by centrifugation $(10,000 \times g$ for 30 min), suspended in buffer A $(50 \mathrm{~mm}$ Tris$\mathrm{HCl}$ buffer, $\mathrm{pH} \mathrm{7.7,} \mathrm{containing} 100 \mathrm{~mm} \mathrm{NaCl}$ and $50 \mathrm{mM} \mathrm{K}_{2} \mathrm{SO}_{4}$ ) and then dialyzed against the same buffer.

Step 4. Column chromatography on DEAEcellulose (DE-52). The dialyzed solution $(90 \mathrm{ml})$ was applied to a DE-52 column $(5 \times 25 \mathrm{~cm})$ previously equilibrated with buffer
B (20 mm potassium phosphate buffer, $\mathrm{pH} 7.5$, containing $5 \mathrm{mM} \mathrm{K}_{2} \mathrm{SO}_{4}$ and $200 \mathrm{mM} \mathrm{NaCl}$ ) at the flow rate of $2 \mathrm{ml}$ per $\mathrm{min}$ and $20 \mathrm{ml}$ fractions were collected. The elution pattern is shown in Fig. 1. The active fractions $(62 \sim 72)$ on column chromatography on DE-52 were pooled.

Step 5. Column chromatography on ButylToyopearl $650 \mathrm{~s}$. The pooled fractions $(210 \mathrm{ml})$, described above, were supplemented with ammonium sulfate to $35 \%$ saturation. The resulting solution was applied on a Butyl-Toyopearl $650 \mathrm{~s}$ column $(3 \times 35 \mathrm{~cm})$ previously equilib-

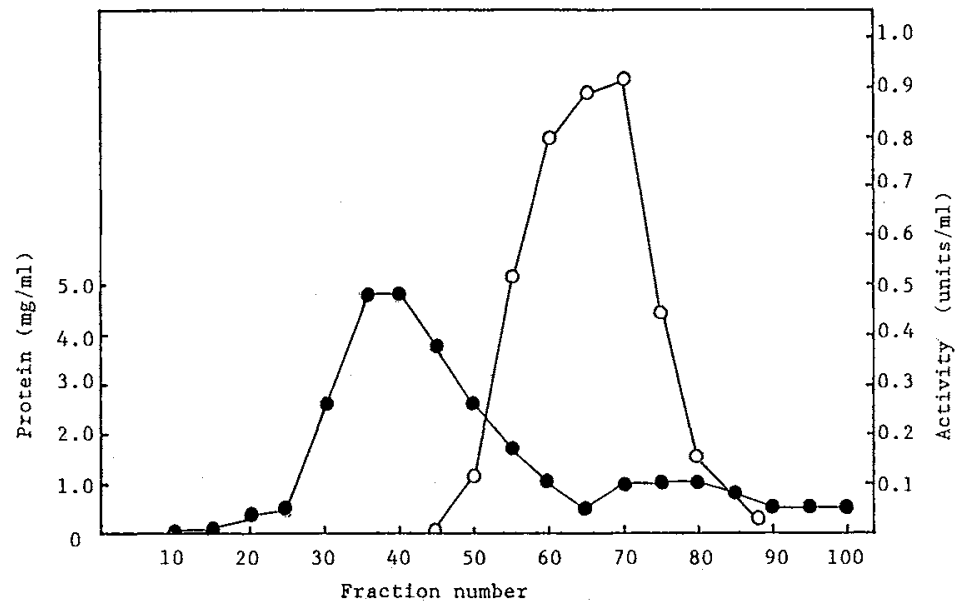

Fig. 1. Elution Profile of Porphyra Ferredoxin-sulfite Reductase on a DEAE-cellulose Column. $\mathrm{O}-\mathrm{O}$, enzyme activity in units per $\mathrm{ml}$; , amount of protein in milligrams per $\mathrm{ml}$.

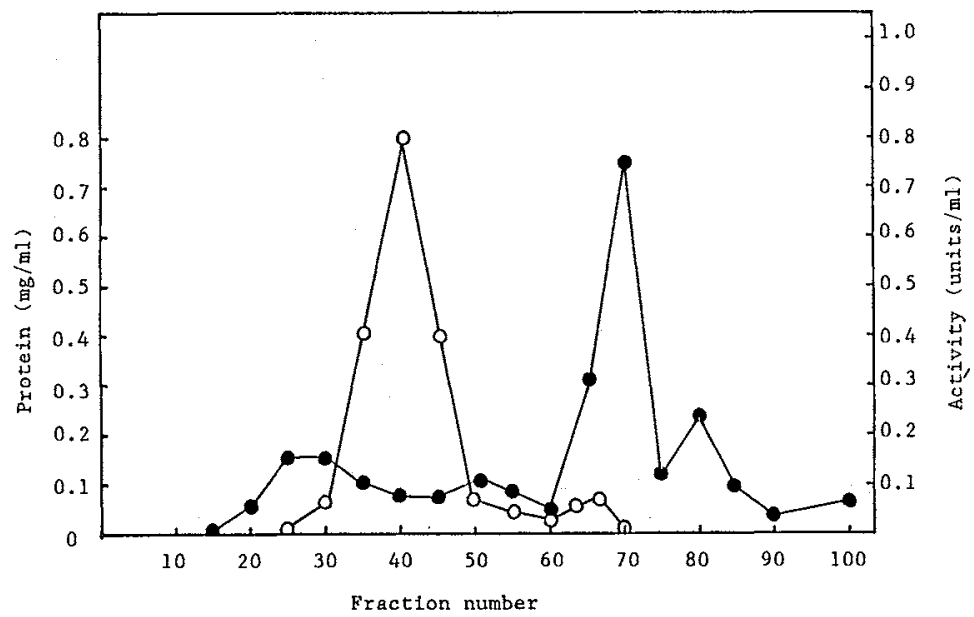

Fig. 2. Elution Pattern of Porphyra Fd-SiR on a Butyl Toyopearl Column. 
rated with buffer $\mathrm{B} 35 \%$ saturated with ammonium sulfate. After the column had been washed with the same buffer, a linear concentration gradient of the eluent was established with $500 \mathrm{ml}$ of equilibrating buffer in the mixing vessel and $500 \mathrm{ml}$ of buffer $B$ in the reservoir. Elution was performed at the flow rate of $0.8 \mathrm{ml}$ per min and $10 \mathrm{ml}$ fractions were collected. A typical chromatographic pattern obtained is shown in Fig. 2. The eluates in tubes $32 \sim 47$ in Fig. 2 were combined and concentrated in a dialysis sac against buffer B
$75 \%$ saturated with ammonium sulfate. The precipitate formed in the dialysis sac was collected by centrifugation at $18,000 \times g$ for $10 \mathrm{~min}$ and then dissolved in a minimal amount of buffer $\mathrm{C}(20 \mathrm{~mm}$ potassium phosphate buffer, $\mathrm{pH} 7.5$, containing $150 \mathrm{~mm}$ $\mathrm{K}_{2} \mathrm{SO}_{4}$ ).

Step 6. Gel filtration on Sephadex G-100. The enzyme solution obtained above $(3 \mathrm{ml})$ was filtered through a Sephadex G-100 column $(2 \times 90 \mathrm{~cm})$ equilibrated with buffer $C$. Elution was performed with the same buffer (flow rate,

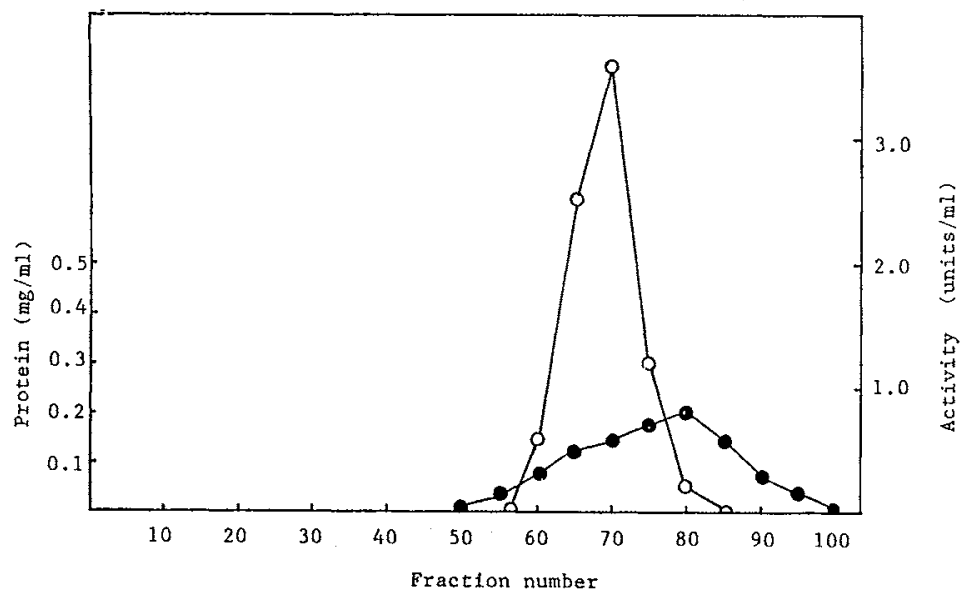

Fig. 3. Sephadex G-100 Gel Filtration.

$\mathrm{O}-\mathrm{O}, \mathrm{Fd}-\mathrm{SiR}$ activity; protein.

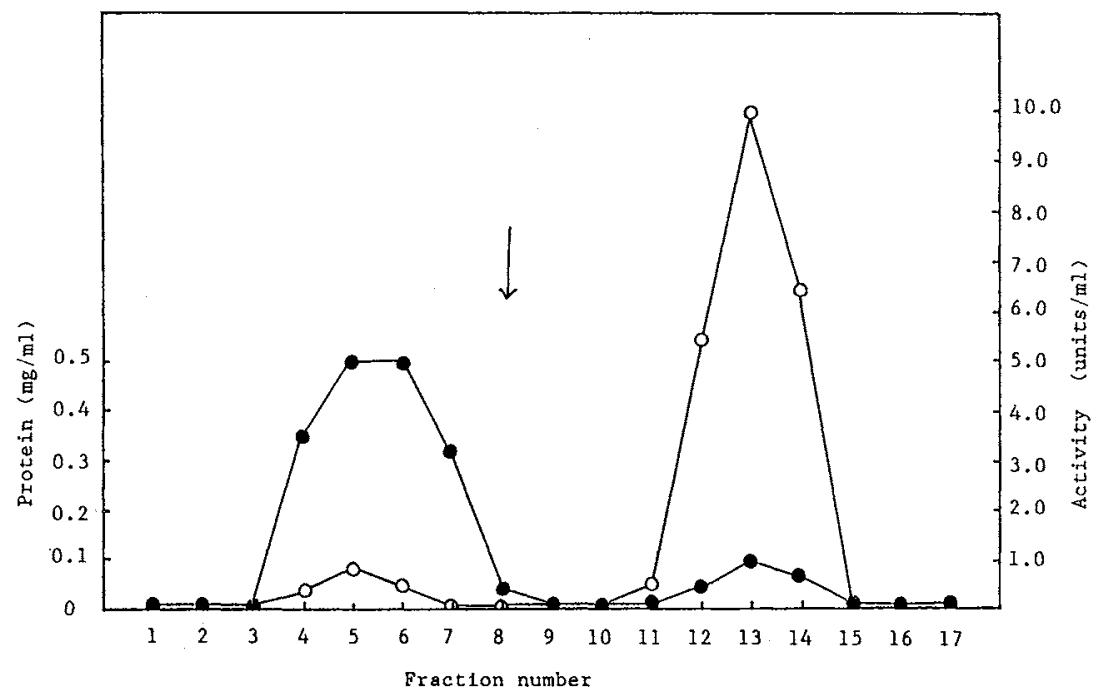

Fig. 4. Ferredoxin-Sepharose Affinity Chromatography.

$\mathrm{O}-\mathrm{O}, \mathrm{Fd}-\mathrm{SiR}$ activity; - , protein. The arrow indicates the point at which buffer $\mathrm{D}$ was replaced by buffer $\mathrm{C}$. 
$0.3 \mathrm{ml} / \mathrm{min}$ ) and $2 \mathrm{ml}$ fractions were collected. Figure 3 shows the elution pattern. The active factions $(65 \sim 73)$ were combined, concentrated with Sephadex G-100 powder and then dialyzed against buffer $\mathrm{D}\left(30 \mathrm{mM}\right.$ Tris $-\mathrm{H}_{2} \mathrm{SO}_{4}$ buffer, $\mathrm{pH} 7.8$, containing $1 \mathrm{mM} \mathrm{K} \mathrm{K}_{2} \mathrm{SO}_{4}$ ).

Step 7. Column chromatography on ferredoxin-Sepharose. The dialyzed enzyme solution $(5 \mathrm{ml})$ was diluted 2 times with deionized distilled water and then applied to a column of ferredoxin-Sepharose 4B $(2 \times 2 \mathrm{~cm})$ previously equilibrated with buffer $D$. Undesired proteins were removed from the column by washing with the equilibrating buffer and Fd-SiR was eluted afterwards with buffer $\mathrm{C}$ (Fig. 4).

The fractions showing specific activities of higher than 95 units/mg of protein were pooled and concentrated with Sephadex G-100 powder, and used as the isolated enzyme in the subsequent experiment.

Table $I$ is a summary of the purification, starting from $1 \mathrm{~kg}$ of Porphyra thalli. In this experiment the final preparation represented about 1136-fold purification over the ammonium sulfate fraction and the recovery was $11 \%$.

\section{Properties of the purified enzyme}

(1) Purity of the enzyme. When the isolated enzyme was subjected to disc PAGE, a single intensely stained protein band was observed (Fig. 5a).

Table I. PurIfICATION of Fd-SiR from Porphyra yezoensis

\begin{tabular}{lcccc}
\hline Fraction & $\begin{array}{c}\text { Activity } \\
\text { (units) }\end{array}$ & $\begin{array}{c}\text { Protein } \\
(\mathrm{mg})\end{array}$ & $\begin{array}{c}\text { Specific activity } \\
\text { (units/mg protein) }\end{array}$ & $\begin{array}{c}\text { Yield } \\
(\%)\end{array}$ \\
\hline$\left(\mathrm{NH}_{4}\right)_{2} \mathrm{SO}_{4}(30 \sim 85 \%)^{a}$ & 175 & 2000 & 0.088 & 100 \\
DEAE-cellulose $_{\text {Butyl-Toyopearl }}$ & 125 & 190 & 0.66 & 71 \\
Sephadex G-100 & 90 & 18 & 5.0 & 51 \\
Ferredoxin-Sepharose $^{b}$ & 50 & 2.9 & 17.0 & 29 \\
\hline
\end{tabular}

a Starting with $1 \mathrm{~kg}$ of Porphyra yezoensis.

b Ferredoxin from Spinacia oleracea.
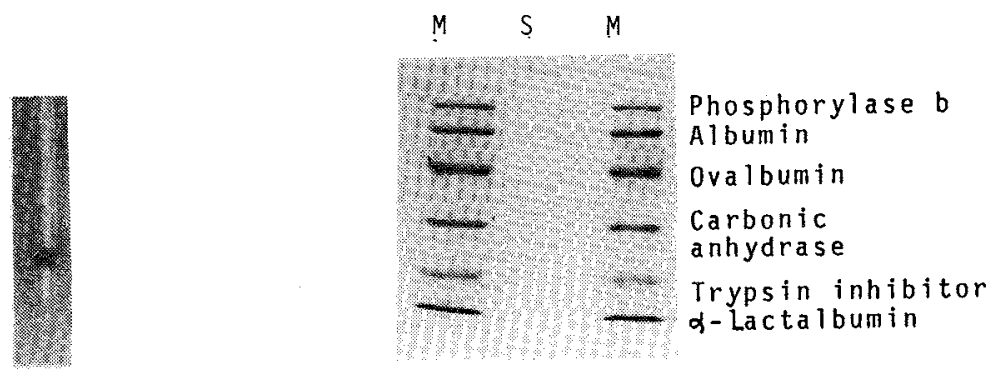

PAGE

(a)
SDS-PAGE

(b)

Fig. 5. Electrophoresis of the Purified Fd-SiR.

(a) Analytical (10\% polyacrylamide) disc gel electrophoresis of about $50 \mu \mathrm{g}$ of the enzyme preparation. A constant electric current ( $4 \mathrm{~mA}$ per tube) was applied for $2 \mathrm{hr}$.

(b) SDS slab-PAGE of $2 \mu \mathrm{g}$ of the purified Fd-SiR on $12 \%$ polyacrylamide gel. Proteins were stained with Coomassie brilliant blue G 250 . S, Fd-SiR; M, marker proteins. 
(a)

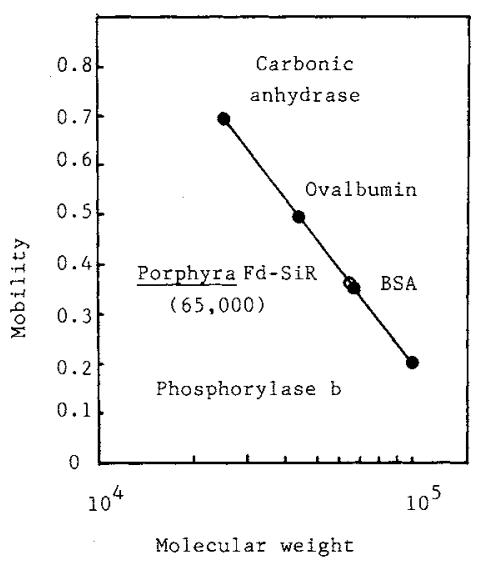

(b)

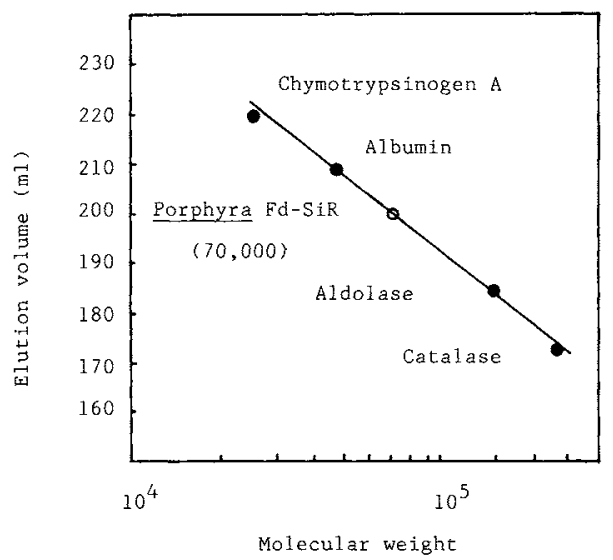

Fig. 6. Determination of the Molecular Weight of Porphyra Fd-SiR

(a) Determination of the molecular weight of Porphyra Fd-SiR by SDS-PAGE. The electrophoretic mobilities (mobilities relative to that of Malachite green) of the marker proteins and $\mathrm{Fd}-\mathrm{SiR}$ are shown. The marker proteins have the following molecular weights: phosphorylase B $(92,500)$, bovine serum albumin $(66,200)$, ovalbumin $(45,000)$, carbonic anhydrase $(31,000)$, trypsin inhibitor $(20,100)$ and $\alpha$-lactalbumin $(14,400)$.

(b) Measurement of the molecular weight of Fd-SiR by Toyopearl HW-55 filtration. Fd-SiR $(600 \mu \mathrm{g} / \mathrm{m})$ and the marker proteins $(2 \mathrm{mg} / 0.2 \mathrm{ml})$ were separately filtered on a column of Toyopearl HW- $55(2 \times 100 \mathrm{~cm})$ in TGK-100 buffer. The marker proteins used were catalase $(240,000)$, aldolase $(158,000)$, albumin $(45,000)$ and $\alpha$-chymotrypsinogen A $(25,000)$.

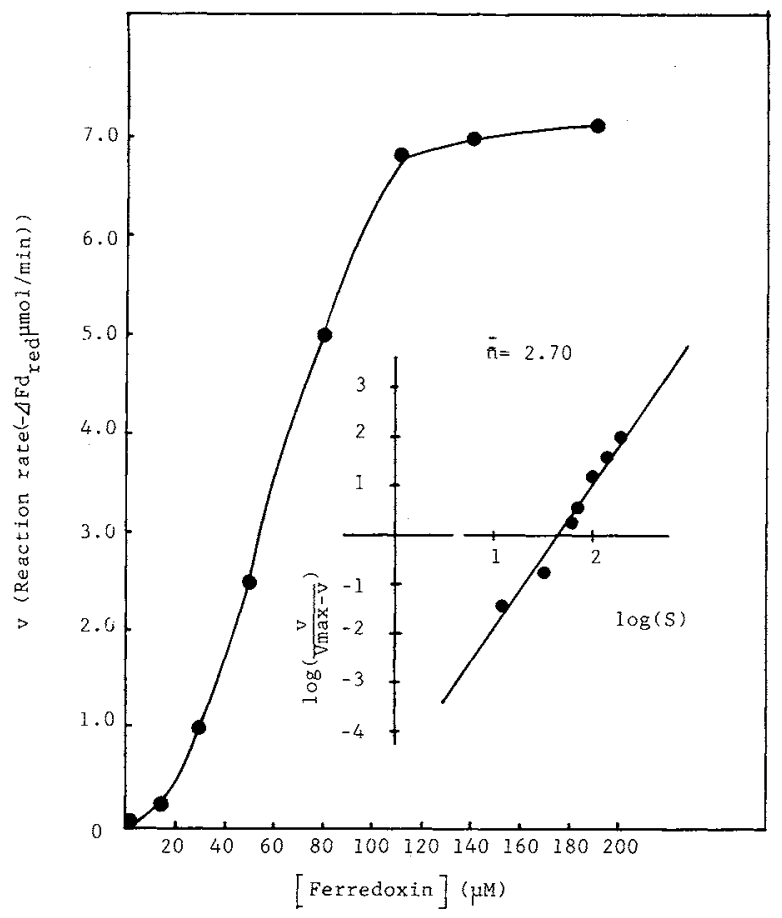

Fig. 7. Effect of the Porphyra Ferredoxin Concentration on the Fd-SiR Activity of Porphyra Fd-SiR.

The amount of protein used in each assay was $5 \mu \mathrm{g}$. The Hill coefficient $(\bar{n})$ is shown in the inset. 
(2) Molecular weight. The molecular weight of the isolated Fd-SiR was estimated by SDSPAGE. The preparation gave a single protein band on SDS-PAGE (Fig. 5b). In Fig. 6a, the $R f$ values (mobilities relative to Malachite green) for the standard protein's subunits were plotted against the known molecular weights of the subunits. The $R f$ value for the purified enzyme was 0.38 , corresponding to a molecular weight of 65 kilodaltons. Furthermore, the molecular weight of this enzyme in a high ionic strength solution was also determined by gel filtration on a Toyopearl HW-55 column $(2 \times 90 \mathrm{~cm})$ equilibrated with TGK-100 buffer. Figure $6 \mathrm{~b}$ shows a plot of the elution volumes for the marker proteins against their molecular weights. The elution volume of the isolated Fd-SiR was $203 \mathrm{ml}$, corresponding to 70 kilodaltons.

(3) Catalytic properties. The effect of the ferredoxin concentration of Fd-SiR activity of the enzyme is shown in Fig. 7. A plot of ferredoxin concentration versus velocity yield- ed a curve that did not obey the MichaelisMenten equation. The Hill coefficient $(\bar{n})$ obtained from the Hill plot was 2.70 , suggesting the presence of multiple binding sites for ferredoxin on the enzyme molecule, interacting in a positive cooperative manner. The plots of sulfite concentration versus velocity also yielded a curve that did not obey the Michaelis-Menten equation. The Hill coefficient $(\bar{n})$ calculated from a Hill plot of the data was 2.30 (Fig. 8).

(4) Absorption spectrum. The absorption spectrum of the enzyme in the oxidized form is shown in Fig. 9. Absorption maxima were observed at 278 (protein peak), 390 (Soret band), 586 ( $\alpha$-band) and 714 (CT band) nm. The absorbance ratios 390 to $278 \mathrm{~nm}$ and 586 to $278 \mathrm{~nm}$, are 0.32 and 0.10 , respectively. Since this absorption spectrum is similar to that reported by Siegel and Davis for the $\beta$ subunit of $E$. coli NADPH-sulfite reductase, ${ }^{17}$ ) it can be concluded that the Porphyra FdSiR molecule contains a siroheme-containing

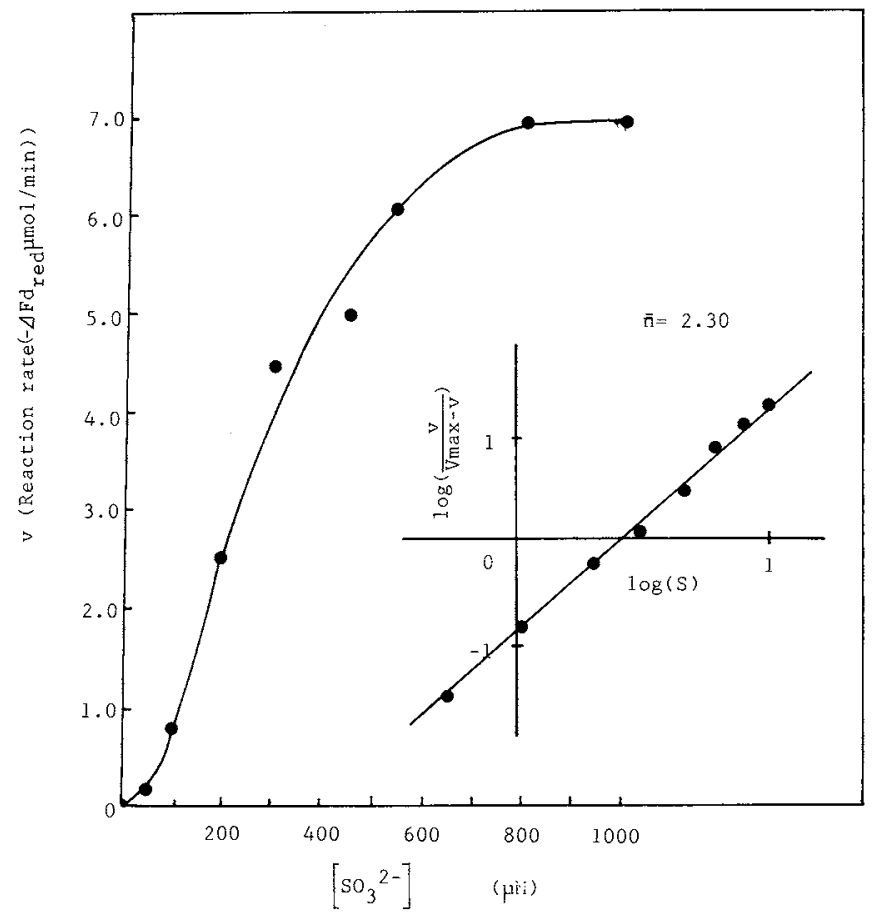

Fig. 8. Effect of the Sulfite Concentration on the Fd-SiR Activity of Porphyra Fd-SiR.

The amount of protein used in each assay was $5 \mu \mathrm{g}$.

The Hill coefficient $(\bar{n})$ is shown in the inset. 


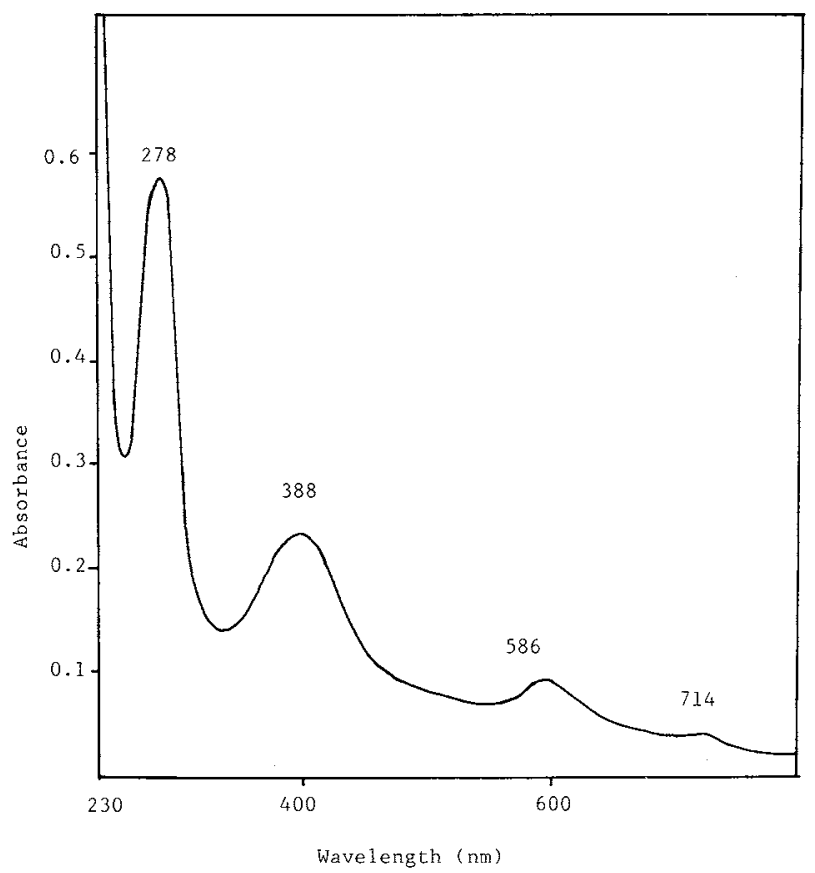

Fig. 9. Absorption Spectrum of the Purified Porphyra Fd-SiR. The enzyme concentration was $600 \mu \mathrm{g}$ of protein per $\mathrm{ml}$ of buffer $\mathrm{C}$.

prosthetic group.

(5) Amino acid composition. The results of amino acid analysis of the isolated Fd-SiR are presented in Table II. The purified Fd-SiR sample was extracted from the polyacrylamide gel after electrophoresis in the presence of SDS. The molarity of each amino acid for the Fd-SiR was calculated on the basis of the molecular weight determined by SDS-PAGE.

(6) Dot immunoblotting analysis. The results of dot immunoblotting analysis are presented in Fig. 10. The anti-Porphyra Fd-SiR reacted with not only Porphyra Fd-SiR but also with the enzyme from other photosynthetic organisms, including a filamentous cyanobacterium and two kinds of higher plants, and gave a single precipition dot. Also, the results suggest that the several Fd-SiRs mentioned above possess antigenic determinants in common and are extremely similar in structure. So it might be concluded that Fd-SiRs from several photosynthetic organisms probably arose from a common ancestor, although they appear to have diverged to a great degree in structural

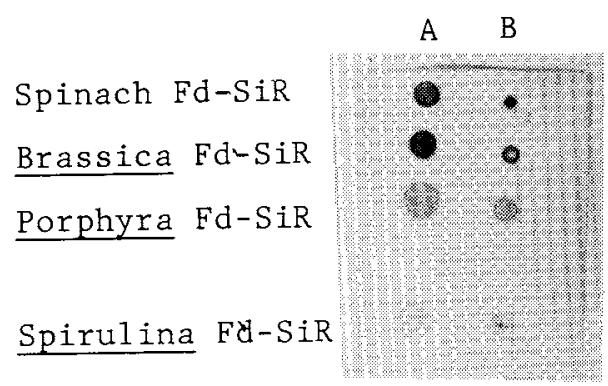

Fig. 10. Dot Immunoblotting Analysis of Fd-SiRs from Different Sources.

A: Ten microliter drops of the Fd-SiR solutions $(300 \mu \mathrm{g} / \mathrm{ml})$ were spotted on the a dry Biodyne nylon membrane sheet with a Drummond microdispenser.

B: The enzyme solutions $(300 \mu \mathrm{g} / \mathrm{ml})$ supplemented with an amount of one microliter.

features.

\section{Discussion}

Methyl viologen-sulfite reductase (MVSiR) (hydrogen-sulfite: (acceptor) oxidoreductase, EC 1.8.99.1) which can reduce sulfite 
Table II. Amino Acid Compositions of Porphyra AND SPINACH Fd-SiRs

\begin{tabular}{lccc}
\hline & \multicolumn{3}{c}{ Residues/subunit weight } \\
\cline { 2 - 4 } Residue & $\begin{array}{c}\text { Porphyra } \\
\text { Fd-SiR }\end{array}$ & $\begin{array}{c}\text { Spinach } \\
\text { 63 K SiR }\end{array}$ & $\begin{array}{c}\text { Spinach } \\
\text { 69 K SiR }^{a}\end{array}$ \\
\hline Asx & 63 & 62 & 66 \\
Thr $^{d}$ & 33 & 31 & 32 \\
Ser $^{d}$ & 29 & 31 & 32 \\
Glx & 63 & 65 & 70 \\
Pro & 30 & 32 & 31 \\
Gly & 63 & 52 & 52 \\
Ala & 68 & 31 & 36 \\
Val & 34 & 43 & 45 \\
Met & 16 & 13 & 14 \\
Ile & 26 & 29 & 31 \\
Leu & 52 & 53 & 59 \\
Tyr & 22 & 21 & 22 \\
Phe & 24 & 26 & 26 \\
Lys & 35 & 39 & 42 \\
His & 16 & 7 & 8 \\
Arg & 37 & 38 & 38 \\
Cys & $8^{b}$ & $5^{b}$ & $5^{b}$ \\
Trp & $c$ & $c$ & $c$ \\
& & & \\
\hline & & & \\
\hline
\end{tabular}

Details of the hydrolysis method are given under Materials and Methods.

a Data of Krueger and Siegel. ${ }^{22)}$

$b$ Measured as cysteic acid after performic acid oxidation.

c Not determined

a Calculated by extrapolation to zero time of hydrolysis.

has been purified from a vriety of photosynthetic organisms, including higher plants $\mathrm{s}^{1,2,18)}$ and algae. ${ }^{4,5}$ )

These enzymes cannot utilize any kinds of physiological electron donor. ${ }^{19,20)}$ More recently, however, we reported the occurrence and extensive purification of plant type (including higher plants and a cyanobacterium) sulfite reductases (Fd-SiRs) (hydrogen-sulfite: ferredoxin oxidoreductase, EC 1.8.7.1), which can utilize reduced ferredoxin as a physlological electron donor. ${ }^{7,12,21 \text { ) }}$

The present paper described a novel method for purifying Fd-SiR from the thalli of a red alga, Porphyra yezoensis. This enzyme, now purified 1136-fold, behaved as an almost homogeneous protein on polyacrylamide gel electrophoresis at pH 8.9 (Fig. 5a). The specific activity of the purified Fd-SiR $(100 \mu \mathrm{mol}$ of reduced ferredoxin oxidized per min per milligram of protein) seems to be the highest value reported so far under the assay conditions described. When subjected to the methyl viologen-sulfite reductase assay, the purified Fd-SiR showed lower specific activity ( $20 \mu \mathrm{mol}$ of reduced methyl viologen oxidized per min per milligram of protein).

On SDS-PAGE, the molecular weight of the isolated Porphyra Fd-SiR was estimated to be 65 kilodaltons, i.e., about the same as those of enzymes from Spirulina platensis ${ }^{7)}$ and Brassica chinensis. ${ }^{12)}$ The molecular weights of Fd-SiRs from Spinacia oleracea ${ }^{21}$ and Spirulina platensis ${ }^{7)}$ so far reported are in the range of $120 \sim 136$ kilodaltons, as determined on gel filtration under high ionic strength conditions, i.e., with $100 \mathrm{~mm} \mathrm{~K}_{2} \mathrm{SO}_{4}$. This suggests that these two enzymes maybe have dimeric forms under these conditions. However, the gel filtration of Porphyra Fd-SiR in the presence of $100 \mathrm{mM} \mathrm{K}_{2} \mathrm{SO}_{4}$, gave a value of 70 kilodaltons, i.e., the same as that of the enzyme from Brassica chinensis, indicating the presence of a monomer in this ionic environment. In comparison with these results, the molecular weights of highly purified MV-SiRs so far reported are in the range of $83 \sim 85$ kilodaltons; Asada et al. for spinach leaves and Saito and Tamura for Porphyra thalli. ${ }^{4.5)}$

When the absorption spectrum of Porphyra Fd-SiR is compared with that of the $\beta$-subunit (a siroheme-containing protein) of NADPHsulfite reductase from Escherichia coli, ${ }^{22)}$ it can be readily seen that these enzymes are very similar in their chromophoric properties. Thus, the Porphyra Fd-SiR exhibits absorption maxima at $278,390,586$ and $714 \mathrm{~nm}$, which are comparable to the $280,386,587$ and $714 \mathrm{~nm}$ for the $\beta$-subunit of the $E$. coli enzyme. This suggests that these two enzymes, together with so far reported Fd-SiRs from other chlorophyllous plants, may have basically similar functional groups, despite their different sources, and further that Porphyra FdSiR, like the $\beta$-subunit of the $E$. coli NADPHsulfite reductase, has siroheme as its pros- 
thetic group. In our previous paper, ${ }^{7,12,21)}$ we reported that Fd-SiRs from Spinacia, Brassica and Spirulina all exhibit absorption maxima at $278 \sim 279,385 \sim 388,585 \sim 590$ and $714 \mathrm{~nm}$, indicating the presence of siroheme. In contrast to the Fd-SiRs cited, the methyl viologenlinked SiR from Porphyra yezoensis thalli reported previously does not contain siroheme. ${ }^{5)}$ The absorption spectrum of the Porphyra MV$\mathrm{SiR}$, with a maximum at $385 \mathrm{~nm}$ and slight shoulders at $408,456,600$ and $664 \mathrm{~nm}$, is somewhat different from Fd-SiRs described.

It may be of some interest to point out the difference in amino acid composition between higher plant and algal Fd-SiRs. When compared with the 63- and 69-kilodalton Fd-SiRs from spinach leaves, Porphyra Fd-SiR contains significantly greater amounts of Gly, Ala, His and Cys per molecule than the spinach FdSiRs. Antiserum against Porphyra Fd-SiR was also used to determine immunologically the cross reactivities to other plant Fd-SiRs. Immunoprecipitin dots were obtained between anti-Porphyra Fd-SiR and other plant FdSiRs. And also it might be concluded that FdSiRs from a rather wide range of photosynthetic organisms probably arose from a common ancestor, although they appear to have diverged to a great degree in structural features. Now, it remains to be established whether Fd-SiR and MV-SiR have basically different protein structures or the latter enzyme is an artifact derived from the native Fd$\mathrm{SiR}$ in an early step of the purification.

Acknowledgments. We are indebted to Dr. Sukekatsu Nozaki of Josai University for his guidance in amino acid analysis of Fd-SiRs. We are also grateful to Dr. Kazuo Fukushima of Nihon University School of Dentistry, Matsudo, for his guidance in preparation of the antiserum. We also wish to thank Messrs. Hitoshi Takahashi and
Takaharu Hayakawa for preparation of Porphyra ferredoxin and for their assistance in some of the experiments reported in the paper.

\section{References}

1) G. Tamura, J. Biochem., 57, 207 (1965).

2) K. Asada, G. Tamura and R. S. Bandurski, J. Biol. Chem., 244, 4904 (1969).

3) A. Schmidt and A. Trebst, Biochim. Biophys. Acta, 180, 529 (1969).

4) E. Saito, G. Tamura and S. Shinano, Agric. Biol. Chem., 33, 860 (1969).

5) E. Saito and G. Tamura, Agric. Biol. Chem., 35, 491 (1971).

6) A. Schmidt and J. D. Schwenn, Abstracts of Papers, 2 nd International Congress on Photosynthesis, Stresa, 1971, p. 507.

7) O. Koguchi and G. Tamura, Agric. Biol. Chem., 52, 373 (1988).

8) E. Saito, K. Wakasa, M. Okuma and G. Tamura, Bulletin of the Association of Natural Science, Senshu University, 3, 45 (1970).

9) K. Tagawa and D. I. Arnon, Nature, 195, 537 (1978).

10) M. Shin and R. Oshino, J. Biochem., 83, 357 (1978).

11) F. Yoneda, Methods in Enzymology, 66, 267 (1980).

12) O. Koguchi, H. Takahashi and G. Tamura, Agric. Biol. Chem., 52, 1867 (1988).

13) U. K. Laemmli, Nature, 227, 680 (1970).

14) L. Ornstein and B. J. Davis, Ann. N. Y. Acad. Sci., 121, Art. 2, 305 (1964).

15) M. M. Bradford, Anal. Biochem., 72, 248 (1976).

16) P. K. Nakane, J. Histochem. Cytochem., 16, 557 (1968).

17) L. M. Siegel and P. S. Davis, J. Biol. Chem., 249, 1587 (1974).

18) G. Tamura, K. Asada and R. S. Bandurski, Plant Physiol., 42, S36 (1967).

19) G. Tamura and S. Itoh, Agric. Biol. Chem., 38, 225 (1974).

20) G. Tamura, "Shokubutsu-Koso Tanpakushitu Kenkyuho." ed. by Y. Morita et al., Kyoritsu Shuppan, Tokyo, 1976, p. 356.

21) J. Aketagawa and G. Tamura, Agric. Biol. Chem., 21, 2892 (1980).

22) R. J. Krueger and L. M. Siegel, J. Biol. Chem., 21, 2892 (1982). 